\title{
SOCIAL INEQUITY AS A PRODUCT OF PUBLIC POLICIES IN THE FISCAL FIELD IN POST-COMMUNIST ROMANIA
}

\author{
Mihnea PREOTESI 1 \\ DOI: 10.35782/JCPP.2020.1.01
}

\begin{abstract}
This analysis is based on the premises that social, economic and fiscal policies can discriminate in a legitim manner certain categories against others only from the perspective of 3 types of reasons: economic criteria; social criteria; meritocratic criteria. From this perspective, any comparative advantage offered to certain groups or individuals, which can not be justified by any of these 3 legitim criteria of discrimination, is actually a privilege, unjustified from the public policies perspective. Even when these advantages follow the logic of differencing based on such legitim criteria, this differencing should be reasonable (to fulfil the condition of social equity as is defined in the theoretic and conceptual frame of this analysis). In Romania, there are significant differences, which do not follow the logic of discrimination according to any of the 3 mentioned criteria, from the perspective of rights, neither from that of obligations. On the other side, even when these are legitim from the above-mentioned perspective, the level of these differences is hard to justify. The differences address categories of people, but are not present on inter-categories level: between the residents connected to centralized heating system (massive subvention regardless the income) and those unconnected (no subvention); the pensions calculated according to different stages of contribution - the entire period, last 5 years, best 5 years, no correlation with the contribution but only with the last month salary. Health insurance is paid only by certain categories, regardless the income, other are excepted also, disregarding the income and some categories pay the contribution to a minimum level, regardless the income. Plus, the level of these differences is unjustified and unjustifiable. The "special" part of the special pensions exceeds in some cases 15 times over the part according to contribution and with the legal possibility unlimited increasing of this non-contributory part for certain categories. The hypothesis I intend to present in this analysis is that this accelerate increasing of the social inequity in the post-communist Romania is the product of establishing and functioning of certain power relations reflected in political decisions that favour one part of the population and disadvantage, correlative, another part of the population. The inequality increased not only based on the meritocratic mechanisms functioning within the economic context of free competition, but mainly based on elite selection mechanisms and social, privileged, un-meritocratic mobility.
\end{abstract}

Key words: inequity, wage policies, special pensions, privileges.

1 Senior Researcher, The Research Institute for Quality of Life, Romanian Academy, E-mail: mihneapre1@yahoo.com 


\section{Introduction}

The analysis proposed in this article exctracts a part of a larger analysis project, which targets the mechanisms and factors which configure the process of social polarization, focusing on the middle class in post-communist Romania ${ }^{1}$. The first 10 years of postcommunist transition in Romania have caused an accelerated growth of poverty and social inequality. In the 8 year period of economic growth which followed, although there was a consistent decrease in the absolute rate of poverty, this tendency was not associated with a decrease in inequality. In fact, with the implementation of the universal tax rate, in the first years following 2005, the inequality started increasing in an accelerated manner, then moderately decreasing in the 2007-2010 period. The period of sustained economic growth was abruptly intrrerupted by the socially impactful economic crisis of the 2009-2011 period.

The income structure likewise undergoes a differentiated evolution in the postcommunist era. In the 2005-2008 period, some important changes occur in the income structure. During this period, pensions (which had fallen behind significantly compared to salaries) increase at the higher rate than the GDP, salaries and all other types of income. Most pensions remain however, despite this significant growth, at extremely low levels, which provide a standard of living barely on the level of basic survival. However, pensions remain the social transfers with the greatest impact in reducing poverty.

On the other hand, social transfers other than pensions contribute to reducing poverty at a less significant rate than any other EU country. At a more general level, the analysis of the social policies of transition (Zamfir (coord.), 1999, 2000, Zamfir, Stănescu (coord). 2010, Preotesi, 2016, 2018) reveals the fact that the percentage of social public expenses out of the GDP is constantly under the EU average in the entire postcommunist period. At the same time however, certain types of income grew at an accelarated rate all throughout this period. Among thse types of income you can find a large part of the salaries from certain state companies, in the first part of the postcommunist period, and later, from government agencies and regulatory bodies and the so called special pensions which, thanks to the laws regulating them, could reach sums that could be considered excessive even for some of the more developed EU countries. ${ }^{2}$

The economic crisis, which had a profound impact in Romania starting with the year 2009 represented the starting point for a first attempt to reform the government worker salaries and the public pension system, after a 20 year period of permanent, reactive and legislative changes which generated important inequities in the two income distribution systems.

In conditions of crisis and resource scarcity, the moral criterion as a structural determinator of social equity becomes exceedingly important and present in the public space.

1 Analysis developed within the research: Zamfir C., Stănescu I. (coord.), (2019). Romania. 19892019: Social Policies and Strategic Ooptions, The Research Institute for Quality of Life

2 There are major differences between these special pensions, and between categories of pensioners who receive special pensions 
An important theme adressed in this context was that of the discrepancies in the field of government workers salaries and so the so called special pensions, as opposed to the traditional pensions, which rely excluvisely on contributivity. Certain categories that were succeptible to being privileged were identified, with categories such as aviators or magistrates being singled out. Aditionally, certain categories of institutional employees were identified as being privileged, such as those serving in regulatory authorities and state companies.

On the other hand, the succesive changes in the pension laws generated inequities in the contributive pension system, materialized as different benefits for similar conditions regarding work and contributivity. The 3 pension laws (19/2000, 263/2010 and 153/2017) were aiming to reduce these discrepancies and inequities.

The post-crisis period, especially in the last 2 years, has, in conditions of economic growth, led to a "relaxation" of the aforementioned moral criteria and the further progress of these discrepancis and inequities. The incomes of the people named in reglementation authorities and administration councils have grown unrelated to their performance, of that of their respective institutions, large pensions have grown even larger, while most salaries and pensions have remained at a modest level, even though the procentual increase was significant, because of the small values to which it was applied, the real growth of these incomes wasn't felt in a significant way.

Raising the ceiling on granting the child support indemnity has led to ridiculous situations in which there were some beneficiaries who, for 2 years, received sums to the order of tens of thousands of euros, based on some, in most cases conjectural, social contributions, which were 100 times lower than the sum granted (the percentage of the contribution, according to $\mathrm{MMJS}^{1}$, was $0.85 \%$, while the benefit was $85 \%$ of the respective income).

All pensioners, including those with special pensions, were exempt from both their medical insurance contributions for their entire pension, no matter its sum and from paying income taxes for the first 2000 lei of their pension.

On the other hand, the discrepancies between pensions based on contributivity and the special pensions have been widened significantly in an artificial way, as a consequence of the change in the way work is taxed ${ }^{2}$. The increase in the gross income, perceived in a very insignificant manner by most of the workforce (especially including those in the private environment) in in the increase of the net income, has instead significantly affected the growth of special pensions, correlated to the gross income, in the context of the significant taxation differences in the two types of income (salaries, taxed on average at $42 \%$, pensions taxed at a maximum of $10 \%$, and only for the part that exceeds 2000 lei).

\footnotetext{
${ }^{1}$ Minister of Labour and Social Justice

2 An eloquent example: a special pension of 36,000 lei increases, as a result of these measures, to 74,000 lei, gross, or 68,800 lei net). (minimum wage on the economy also increases, by 300 lei gross, under 200 lei, net)
} 


\section{Assumptions and premises of the analysis}

The proposed analysis is proposing the following targets:

- the evolution of the inequality and identifying losers and winners in the process of social differentiation

- the evolution of the legislative framework, in the fiscal field, in the field of salaries and pensions

- the diagnosis of the social inequities generated by the various changes in the legislative framework between social categories, as well as inside social categories from a transversal and longitudinal perspective

- the efficiency of social transfers, excluding pensions in reducing poverty and their impact on social inequity

One of the premises assumed in this paper is that the social, economic and fiscal policies can legitimately discriminate certain categories, to the detriment of others, only from the perspective of 3 types of considerations, in correlation with 3 types of criteria: the economic criterion; the social criterion and the meritocratic criterion.

Therefore, from this perspective, any comparative advantage granted to groups or individuals that cannot be justified under any of the 3 legitimate criteria of discrimination is, in fact, a privilege that does not justify addressability from the perspective of public policy. Even when these advantages follow the logic of a differentiation structured on the basis of such legitimate criteria, the level at which these differentiations operate must be a reasonable one (in the sense of fulfilling the condition of social equity, which will be operationalized in shaping the theoretical and conceptual framework of this analysis).

In present-day Romania, there are significant differences, which do not follow the logic of discrimination according to any of the 3 mentioned criteria, both from the perspective of rights and from that of obligations.

On the other hand, even when they are legitimate from the aforementioned perspective, the extent of these differentiations is difficult to justify. The differences refer to categories of people, but they also manifest themselves within each of these categories: between the residents connected to the centralized heating system and massively subsidized (regardless of income), and the unconnected and unsubsidized ones, between the pensioners who receive a correlated pension, either with the contribution for the whole period of activity or for the last 5 years, or, for the highest earning 5 years, for the last 3 months, or without correlation with the contribution, but only with the quantum of the income obtained, in relation to the average income.

Only certain categories pay health insurance, regardless of income, others are exempted, or pay these contributions at a minimum level.

Besides the unjustifiable differences from the proposed perspective, even if there is a (debatable) justification on the criteria of merit, the level at which these differences manifest themselves is unjustified and unjustifiable, in my opinion. 
The "special" part of the special pensions exceeds, in some cases, the appropriate part on the basis of contributivity by 7 times, with the legal possibility that this noncontributory part will continue to grow, unlimited, (only) for certain categories of "special" individuals, with no connection to the contribution, to the salary from the active period, to the economic power of the country, by an exacerbation beyond any limits of rewarding certain merits, in relation to others.

In the case of some of the state-owned companies and some regulatory authorities, privilege mechanisms such as those mentioned above work in a manner that can be regarded as even more unfair, even when compared to the special pensions system (taking into account that in these state institutions employments in key positions/appointments in the Boards of Directors are made by political appointments and not by competition, or based on the acquisition of certified competences).

The selection for the proposed analysis of the system of remuneration of the budgetary system and of the 2 categories (state employees and pensioners, from the contributory system and from the mixed system, with a significant non-contributory component) aims at the exemplarity of these cases, not only from the perspective of the level of privileges, but also from the perspective of the transparent and assumed mode of privilege, by over-appreciation and over-rewarding of some merits and those who hold them.

The hypothesis from which I start the proposed analysis is that this accelerated growth of social inequality in post-communist Romania is, to a significant extent also the product of crystallization and functioning of power relations, reflected in the political decisions that favor a part of the population while exqually disadvantgaging another part of the population is disadvantaged.

\section{Research methods. Data sources}

The research methods I use are the analysis of social documents (unitary pay laws, pension laws), content analysis and participatory observation.

Data sources used were:

- analysis of social documents: the laws of unitary pay: Law 330/2009, Law 285/2010, Law 153/2017; successive variants of the pension law: Law 19/2000, Law 263/2010, respectively, Law 153/2017;

- the results of the content analysis of the media message promoted by some of the important news television stations in Romania during 2010-2012, and between 2015-2018;

- participatory observation by participating in over 60 live shows in 2012-2018 at some of the main news TV stations;

- comments on blogs / sites dedicated to the rights of certain categories of budget with special status (military, police, aviators, magistrates). 


\section{Theoretical and conceptual framework}

The concept of justice is approached dichotomously, from a philosophical perspective, starting from antiquity. In Plato's Republic, two different approaches to the idea of justice are put face to face, as starting points in the configuration of two types of theories of justice:

Thrasymachos character: "In every city, justice is the same as, namely, the use of constituted rule. Or, as he has the power, it is evident to the one who judges well that everywhere justice is the same: the tool of the strongest" (Plato, apud Miroiu, 1996, p.17)

Socrates character: "justice is that virtue that makes it possible for others to become beings and, once they appear, to be preserved, as long as it is there" (ibidem, p.18).

The two approaches to the idea of justice have been reinterpreted, either by idealist philosophers such as Kant or, from the other perspective, by utilitarians, such as Bentham or Hume, both of which are found, in modern theories of justice, synthesized by B. Barry, almost 1300 years after Plato's Republic: Barry identifies the central issue of any theory of justice, "in Plato's time, as in ours (...) the ability to argue in favor of unequal relations between people" (Barry, 1989, p. 3). B.Barry thus defines the two major approaches to the idea of justice: justice as an advantage, and justice as impartiality.

The first approach is the one mainly used by the followers of the utilitarian perspective in the modern approaches to justice, in the tradition of the classics of utilitarianism, Thomas Hobbes and David Hume.

The second acceptance starts from the Kantian idealist view of justice and gains significant notoriety, in the version consecrated with the appearance of a book considered to be one of the most important books of political philosophy of the last century. The author of this book is the liberal philosopher John Rawls, and the book, published in 1971, is called $A$ Theory of Justice.

\section{Justice as social justice. The Liberal Perspective - John Rawls}

In Rawls's book, mentioned above (Rawls, 1971), the author proposes a theory of justice that is built on a few basic principles: freedom, equality and rewards for services that contribute to the public good. Rawls proposes two ideas that underline the idea of justice as fairness, from the perspective of justice as impartiality: the original position and the veil of ignorance.

This involves ignoring one's own social position, one's social skills and opportunities from the perspective of evaluating the frame of reference of the configuration of social justice; "Justice is the most important virtue of social institutions, just as truth is the most important virtue of systems of thought" (Rawls, 1971, p. 3)

42 years after the publication of Rawls's book, another book appeared, which very quickly became a best seller and proposes, this time, a non-Marxist vision on the idea of 
social justice. Capital in the 21st Century, Thomas Piketty's book, published in 2013, which proposes an analysis of social inequality in contemporary Western society, was followed by a recently published book, in which Piketty completes his theory of social justice. Starting from the idea that "every society invents an ideological discourse to justify social inequalities", Piketty considers that in Western society today, inequality is not so much of an economic or technological nature, but rather an ideological and political one. According to the author, "inequalities are not natural, but are created in the 21 st century through a proprietary, entrepreneurial and meritocratic discourse."

Piketty's approach is strongly redistributive and is based on the socialization of assets and properties:

- through progressive taxes with very high marginal tax rates on inheritance and real estate transactions;

- by redistributing the amounts collected to young people, who will all receive 120,000 euros, at the age of 25 .

A common point, both of classical and modern theories on the idea of social justice, is the relation to the concept of merit. Whether merit is associated with social position or with certain individual qualities of the person, the discourse on the idea of justice is built around it. While the liberal approach associates merit to the idea of justice, interpreting the meritocratic system as finding the one that ensures social equity, the approach from the ideological perspective of "the left" puts into question precisely the exacerbation of the idea of merit in constructing a discourse to justify social inequality.

Meritocracy designates " a social state in which the hierarchy of positions exactly imitates that of the individual qualities (talents and merits), a social state in which equality of opportunity reigns. According to the most current version of meritocracy, the school system fulfills this task (of meritocratic selection, nm); the social hierarchy is thus conflated with that of diplomas". (Boudon et al.,1996, p.164).

However, the meritocratic model works differently in the private economic system, compared to the public one. When the function of the mechanisms of social selection and mobility is sanctioned and, respectively, validated by the action of "market" mechanisms, merit is validated by the market and operationalized in measurable forms, associated with the profit brought to the company.

In the budgetary field, the market, although it may play a certain role, is only one of the factors involved in validating and legitimizing an operational definition of the meritocratic mechanism of social mobility within the respective subsystem. Among the important factors that validate the function of this mechanism is the legislative system that regulates it (Preotesi, 2014, p.578).

Income is a strong criterion of differentiation within the middle class, which, as Mills points out, is a non-homogeneous one, "more like a pyramid, than a horizontal layer" (Mills, 1951/1994, p.216, attach. Larionescu, Mărginean, Neagu, 2006, p.24).

The heterogeneity of the middle class in Romania takes the form of social polarization between the upper middle-class, as the level of income and lifestyle, the upper class and 
the lower part of the middle class, having an income level close to that of the lower class, but trying to sustain with limited resources a lifestyle appropriate to the selfperceived social position, specific to the middle class - "the subgroups that make up the middle class in Romania have a common feature: they are constantly pursuing distancing from the lower class and the proximity to the social elite" (Vasile, 2008, p. 373).

The analysis I propose focuses on a part of the middle class, which is under the direct influence of public policies in the field of pensions and salaries, influenced by certain aspects of the income taxation policy.

A complementary perspective, appropriate to the analysis I propose is that of the formation and circulation of elites, from the perspective of the relationship between social position and income level.

Vilfredo Pareto defines the elite in two complementary ways: (1). From the perspective of the socially recognized individual qualities, the elite represents a "social category composed of individuals with the highest share of appreciation in their branch of activity" (Pareto, 1916, Boudon, et al., 1996, p.100). (2). From the perspective of the position occupied in the company-individuals exercising management positions. This category comprises two subcategories: governmental elite and non-governmental elite.

Wright Mills defines the elite by referring to American society in the mid-twentieth century, in relation to the place occupied in the structure of power relations. For Mills, there is an elite of power, representing a total elite that includes the category of elite members who are at the intersection of centers of power: economic, military and political.

Thus, elites are defined either starting with the qualities of individuals or as products and / or generators of a certain type of social relationship. Individually, the two types of definition are different ways of describing the same reality, the subject of the definition, namely the individuals belonging to the elite, being one and the same. But a perfect meritocracy is a utopia, so that the two types of definitions configure different spheres of the content of the term elite.

"An implicit definition of the elite conveyed in the public space introduces certain ambiguities in the practice of using the term, in the sense of automatic attribution, in some cases, of individual attributes used as a selection criterion according to the first type of definition of elites, although the inclusion in this category is made according to the second type of definition. The media plays an important role in maintaining this type of confusion, depending on whether or not it supports certain interests" (Preotesi, 2015, p.92).

The economic capital and the political capital are added to the cultural capital and thus "an elite is created that tends to become a total one, by (re) activating and instrumentalizing the action of a part of the cultural elite, in the sense of promoting the dominant culture of this ruling class - in the sense of given by Bourdieu to the term" (idem).

With the cultural means of maintaining and strengthening domination, in addition to the political and economic ones, this new elite approaches the definition of the total elite given by W.Mills. The interaction between part of this new cultural elite, part of the holders of the means of promoting the dominant culture and part of the vectors of 
promoting the corresponding messages led to the formation of some sub-elites: the media elit - the occupational segment that has the power over the mass media.; ; the intelocratic elite - "that seemingly critical commentator who addresses a non-specialized audience on issues of broad public interest" (Manolache 2009, p.13).

The message transmitted through the media uses certain image vectors that have their own interests, which they are in a position to promote and become sub-elites of function and position. Subjects of the position that promotes itself, in the context in which the interests of the system it represents are convergent with those of the economic and political elite and those of the sub-elites of the position, which promote themselves.

From the content analysis of the broadcasts of the main news stations, validated in the work cited above and supported by my continuing participation as a guest on the respective TV channels, I will summarize some conclusions appropriate to the analysis proposed here.

\section{Summary of the results of the analysis of the media message}

The research (whose conclusions were presented, in Preotesi, 2011/2015) was based on monitoring the reflection of some major themes, such as the crisis and social justice at the main news and debate stations: Realitatea TV and Antena 3, for the period 20092010 and Realitatea TV and Digi 24 TV, for the period 2011-2016. The monitoring included the main programs that aim to debate important and topical issues.

The research objective represented the analysis of the way in which the motivations of the social and political actors are reflected in the discourse on the topic of the crisis, in the first monitored period, respectively, on more general topics concerning the distributive and redistributive mechanisms from the perspective of public policies, in the post-crisis period.

The results of the media analysis were accompanied and validated by a participatory observation made in over 70 live broadcasts at which I participated in the news stations Digi 24 TV, Realitatea TV, TVR Info, B1 TV, between March 2012-March 2019. Among the actors involved in the debate are representatives of the media (analysts and moderators), representatives of the Government, representatives of the political parties, representatives of the Unions, the categories are not strictly unrelated groups, the roles being, in some cases, interchangeable.

\section{Stereotypes and taboos in the public message}

The important topics of the public debate are treated, in general, "according to reductionist, simplistic schemes that carry a body of stereotypes, the quasi-common interest of the actors involved being the promotion of mediocrity and maintaining a status-quo of power relations in society" (Preotesi , 2010).

One of the main conclusions presented in the above study is that promoting a discourse based on ideological stereotypes hinders social innovation that can generate 
uncomfortable solutions to the problems associated with the economic crisis. Such an inconvenient solution would be to change the foundations of a social justice model created and promoted to justify huge social inequalities as the product of a (false) meritocratic mechanism of social selection.

The dominant approach is from a utilitarian perspective, supported by several media stereotypes:

- equalization of salaries and pensions can only be made upwards, and salaries and pensions, including very large ones, cannot be lowered, regardless of their nature (contributory or non-contributory), because they represent an infallible earned right.

- moral arguments are, in general, evaluated together with the economic ones, by promoting reasonings like: "the decrease of very high salaries or pensions, would not lead to a significant difference in the budget".

- the redistributive measures have a rather marginal representation between the solutions proposed to the problems induced by the economic crisis, the agreed measures are positioned outside the moral - an economic measure, which represents, in fact, a certain general orientation, is "supporting the private environment" ", as a " universal panacea "to the negative impact of the crisis.

- to justify the huge discrepancies between categories of employees in the public system, some comparisons are made with the situation in the EU, as a justifying argument for maintaining the privileged status quo of certain categories - for example, the salary of a magistrate in Romania is compared to that of a EU magistrate, without comparing the salaries of other budgetary members with those of their equivalents. In a similar type of logic, as a final and infallible argument, it is stated that the salaries and pensions of the magistrates, which are at a level well above that of the other government employees, would be a requirement of the EU, another often used argument, being that only this can guarantee the independence of justice.

The monitoring of TV shows made during the economic crisis, and in the post-crisis period reveals a contradictory attitudes of the media, regarding the so-called special pensions. While in the early period of the crisis, the very large discrepancy between their average level and the average level of contributory pensions was identified by the media as an unacceptable situation, both from a moral point of view and from an economical one, the same TV stations and some of the same moderators are the ones who later supported the idea of infallibility of the aforementioned earned rights.

The post-crisis period accentuates this "legalistic" approach, the dominant paradigm promoted in the mass media being that of identifying the earned rights of certain categories with social justice. The contradictory attitude mentioned above persists; While the huge discrepancies, in some cases are identified and sanctioned in the public space, this sanction is not accompanied by a rigorous analysis of the fundamentals of the mechanisms that generate such situations. 
In a more general context, the identification of major discrepancies between law and morality does not seem to generate any kind of axiological tensions to those who populate the media space. Phrases such as "it may not be moral but it is legal" are frequently used, without questioning the moral basis of the laws. In addition, the intentional confusion, in my opinion, between rights and justice, contributes to the promotion of a social injustice model as discussed in this chapter.

On the other hand, regardless of the ideological orientation declared more or less explicitly, the approach of rewarding the merits recognized as such, is an ultraliberal one, the discussion being conducted on the nature of the merits identified as such and not on the level of the reward. Very present in the public space is the approach of "if they do their job properly and efficiently, it doesn't matter how well they are paid - even when it comes to public money." In addition, any form of austerity in the public behavior of the political elite it is taxed as "populism". For example, behaviors considered normal in other consolidated democracies, such as the use of public transportation by members of parliament or ministers, in Romania would be considered only populist gestures.

But there are some nuances that need to be explained. Although, as I mentioned above, the dominant approach in the media is that cuts to the pensions and wages are unacceptable in themselves, and wage and pension increases continue to be considered good, in and of themselves, regardless of the pay increases in the public domain, from 2017-2019 and the expected significant pension increases that will follow are considered unsustainable and far too large in relation to the evolutions in the "real economy". With these increases in salaries for budget and pensions, although a dominant "anti-austerity" approach persists, so does the dichotomous approach to those employed by the state and those employed in the private sector. Government employees, as a whole, are considered privileged compared to private sector employees. On the other hand, while the principles underlying the granting of special pensions to certain categories are not questioned, only the excesses that are treated as some kind of collateral effect are questioned. For other categories, such as members of parliament, special pensions are considered unacceptable, although they are at a much lower level than those of the magistrates, for example. Here, the same legalistic reflex appears, of the earned right, the critical approach in the case of the parliamentarians being canceled, thus, in the case of the magistrates. No doubt that denouncing excesses, such as the tens of thousands of lei pensions mentioned above, is present in the media, but the debates about social justice and about the fundamentals of the idea of social justice, they are completely missing. Of the several hundred monitored shows and the more than 70 shows that I participated in, I identified a single reference to the need to discuss the legitimacy of a principle that is at least questionable, that of the earned right. The moderator of that show simply closed the discussion before starting it.

A more general conclusion is that the teleological argumentation of those directly interested in maintaining and reproducing the privileged situation they are in does not generate a counter-argument articulated in the public space.

Synthesis of data collected from websites and blogs dedicated to debating the rights of special-budget government employees 
From the analysis of virtual debate platforms on the special rights of some categories of government employees, some arguments arise that aim to justify the very large discrepancies between salaries and, in particular, the special pensions of some categories of government employees, compared to other "non-special" categories, of which I selected the most frequently invoked.

- incompatibilities and other restrictions on rights related to certain public functions;

- the special nature of the work (in the case of the military);

- the social importance of the work of these categories;

- the need to have a standard of living that will ensure their financial independence and will ensure they will "not be forced" to become corrupt. In the case of magistrates, the independence of the judiciary must also be sustained by ensuring an equally high standard of living after retirement. In the case of the military, the pension is part of a contract that involves a payment for the benefit from the active period and one for the reservist situation.

Although some of these arguments are correct, they do not, in any way, justify the level of rewarding certain merits and compensating for certain efforts. For example, not having the legal possibility of accessing a second job can not be an argument that supports the correctness of a salary 5 times higher than in the case of categories with comparable educational level and social importance of the job.

Using as a benchmark the maximum legally permissible duration of work, of 12 hours per day, assuming that all other state employees would have a second part-time job, a reasonable ratio would be $1: 1.5$, for categories with equivalent education and training, A higher salary would mean a pension based on a higher contribution rate, so the compensation and the reward would be transferred to the inactive period. Except for the military, for whom the way of calculating the pension is different, there is no justification, neither moral, nor economic, nor social, to reward some already overpaid people, with salaries well above the average of those with comparable training and education, with special pensions, in which the non-contributing part exceeds, in some cases, by 15 times the contributing part.

Neither in the case of the military, the police and other categories can the pension values that far exceed the average of the salaries of the last part of the active period be justified.

Therefore, even where the principle of the existence of a special pension can be considered correct, it is necessary to correlate this level with that of the income from the active period, but also with the average of the percentage pension/salary of the pensioners receiving a pension calculated exclusively based on the contribution. If, with regard to certain categories of the defense and public order system, excessively large pensions are rather exceptions, there are categories, such as magistrates and aviators, for which this situation is the rule. Undoubtedly, professions such as the aviator, which, in addition to professional training, involve certain obvious professional risks, should 
be rewarded as such, but here also the salary should represent, through its level, the reward, then transferred, on the basis of taxation, in the higher level of the pension.

The increases in salaries for some categories of state employees, from 2017-2019 deepened the discrepancies between categories of budgetary as well as the discrepancies between budgetary and private employees. In addition to the differentiated positioning by the coefficients allocated by the unitary wage law adopted in 2017, the differentiated mode of law enforcement has been a source of increasing social inequity. While some of the state employees benefited from salary increases, directly at the level foreseen for 2022, for the others this increase was expected to be granted incrementally, during these 4 years. If, with regard to certain categories, such as resident doctors, there is a social, economic and moral justification, they are, at that moment, at a very low and motivating level for medical graduates, for other categories, the justification of this differentiated approach it is more difficult to justify.

The austerity measures from 2010 revealed a pattern of the legitimacy of intangible rights, compared to tangible ones. In addition, the rhetoric of earned rights concerns certain rights already earned, but also rights that will be able to be earned, at one time, this, only in the case of certain pensioners with special pensions (here it is only about magistrates). The change in the taxation system, from 2017 has led to the significant increase of special pensions, which, due to the difference in taxation between the pensions related to the gross salary and the gross salaries and by reporting the pension to the gross salary, have come to significantly exceed the last net monthly income, already artificially raised in the case of some of these "specials", in the last month, the one to which the pension in question is related.

The situation generated could be corrected, with one exception, in the case of the magistrates, for whom the Constitutional Court issued a decision, however challenging, so little commented in the public space, that such a legal scam must be accepted unconditionally, in order to not affect the freedom of justice. In addition, the SCM (communicated by the SCM, July 17, 2019) had a virulent reaction when the possibility of over-taxing the part of the special pensions exceeding 10,000 lei appeared in the public space, an amount considered totally insufficient to partially compensate for the disadvantages of the magistrate position. Also, in a similar way, the Associations of Magistrates and the Association of Retired Magistrates from Romania reacted (https://evz.ro/magistratii-pensionari-se-ridica-impontre-suprataxarii-veniturii-

lor.html). I think it is important to remember, that it would have been about taxing the part that exceeds 10,000 lei of income assimilated to the pensions, but not based on taxation and taxed, at present, at a level of almost 5 times lower than the gross salaries at which it is reported.

While the rights of the pensioners, both the legitimate and the less legitimate ones, as mentioned above, are very difficult to question, under conditions of economic recession, the first rights that can be "attacked" are those of the employees who have not yet received them, that is, those who expect the proposed increases to be given incrementally by applying the unitary wage law. 
The lack of a real public debate on the foundations of social justice represents the premise of the enlarged reproduction of this falsely meritocratic system, in which certain merits are over-rewarded and for other merits, the reward is greatly undersized and possibly deferred.

A utilitarian approach to defining such a situation starts from the premise that for some categories, the merit, once recognized by the company, has been rewarded and, consequently, for other categories, the merit, although acknowledged, has not yet been rewarded and, on the other hand, there is no competition between the two categories, whose interests do not intersect.

The premise of the analysis that I propose is that the interests of the two types of categories are intersected and, under certain conditions, such as those of severe limitation of resources, they can become competing, in this case, those with bargaining power having the upper hand. During the period of "austerity", salaries of 1000 lei were reduced by $25 \%$, while pensions 20 times higher, based only to a small extent on contributory, could not even be reduced by one leu.

While for the private sector, the efficient allocation of resources is a basic, implicit condition of the functioning of a company, for the public sector, it has an influence, on the one hand, more complex, while on the other hand, mediated by several factors.

Any government activity exerts an influence on the allocation of resources. The resources being limited, the production of any good or service implies a cost of giving up the production of another good or service.

"Unlike what the private economy is trying to do spontaneously, the state must guard against the waste of productive resources, allocating them inefficiently (...): the state has a constitutional role as guarantor of the general interest; The waste of resources (...) determines for the community a loss of well-being that can justify the necessity of an intervention to correct the functioning of the public sector. This role is not only limited to the allocation of resources, it also aims to achieve a fair distribution of well-being and of the macroeconomic balance" (Porfiroiu, Iorga, 2009, p.28).

In the upcoming sections, I will illustrate all these considerations presented above, with data on the evolution of pensions and wages, under the impact of public policies.

\section{Comparative analysis of the budgetary unitary wage laws (Law 330/2009, Law 285/2010, Law 153/2017)}

Given the fact that the initiators of the first law on unitary wages called on the German law on unitary wages as a source of inspiration, I think a comparison with the mentioned model would be useful.

From the analysis of the data on the German system of budgetary remuneration (taken from Pârvoiu, 2009), several conclusions have been presented widely in the above mentioned work (Preotesi, 2016), of which I will keep in the present work only one relevant aspect: excluding from comparison the salary of the German Chancellor, the ratio between the minimum wage of a middle-class state employee and the maximum salary does not exceed, in Germany, 1: 5. 
The fundamental difference consists precisely in the excessive differentiation, typical of the Romanian model, of the salaries of some employees with high, comparable education, representatives of the middle class. A relevant example in this regard is that of the ratio between the maximum salary of a high school teacher and the maximum salary of a magistrate, in Germany and in Romania. If in Germany, this ratio is 1: 2.2, in Romania, the ratio, although it was expected to reach, according to the law of 2009 (the actual ratio at that time, being 1:10), 1:2.78, according to the changes of coefficients of the law of 2017 it is foreseen to be around 1: 8 .

Regarding the unitary wage law in Romania, its first form, namely the law 330/2010, establishes a maximum ratio between the extremes of the basic salaries of the budgets of 1:12. Less than one year after the adoption of this law, it is repealed and replaced by law 285/2010. The main difference is the increase of the minimum-maximum ratio from 1:12 to 1:15 and the decrease of the reference value, from 705 lei, to 600 lei.

The Law of 2017 provides for a significant increase in the reference value (the reference becoming the minimum wage in the economy) and a resetting of the coefficients allocated to each group of employees. The laws of unitary pay, even if, declaratively, they intended to reduce the gap between the salaries of some categories of state employees, keeps significant differences between the categories on symmetrical hierarchical positions, differences that increase relative to the highest level. In other words, the maximum salary that you can reach, as a state employee, correlating with reaching a maximum possible level of education, competence and experience in the respective profession, depends more on the chosen field of activity than on the level reached in professional development.

These differences, which were also quite large in Law 330/2009, increase in the new form of the law, the one from 2010 and, by increasing the value of the benchmark, but also by re-establishing the coefficients, significantly increase in the law of 2017, the one that is depicted in the table below, in its variants of 2011 and 2017, represents an illustration of the power relations between the representatives of certain privileged budgetary areas, which are further benefited. by the new form of the law, relative to the other state employees, whose pressure was not sufficient to improve their position in this pay grid.

By the Law of unitary salaries of 2017, the coefficients of multiplication for preuniversity and university professors, researchers and the military significantly decrease. Despite the spectacular increases in the salaries of doctors over the last 2 years, also, in the case of doctors, the coefficients of multiplication decrease, with one exception, the resident doctors, where the increase is not significant, from the point of view of the coefficients.

The gap between magistrates and all the categories mentioned above, although, for some categories, decreases from the perspective of the multiplication coefficients, increases significantly, in absolute values, as a result of the increase of the reference value to which these multiplication coefficients are related.

If we consider the minimum values associated with the positions of beginner for magistrates, compared to all the other categories of budget, the differences are at least 
as difficult to justify. A beginner, still a student at the Superior Institute of Magistracy, receives, in the year II, an income close to the one representing the maximum basic salary of a university professor, and of a level close to that of a primary doctor, and close to the maximum salary of an officer superior of the army or of a policeman at the top of the domain hierarchy.

According to this "unitary" salary law, a newcomer judge receives a salary $50 \%$ higher than the maximum that a university professor can receive and double the maximum of a 1 st grade scientific researcher. All these differences multiply on a much wider scale in terms of the level differences of pensions that magistrates will receive - $80 \%$ of a much higher income, compared to a maximum of $45 \%$, of a much smaller income, in the case of pensions based on contributivity.

As for the other budgets mentioned in comparison, there will also be significant differences between their pensions and those of the magistrates, but, considering that they will also benefit from special pensions, the differences will be proportional (only) to the difference of salary.As can be seen from the table below, the law of 2017 significantly increases these inequalities, already existing in the previous variants of the law and, by increasing the reference value, the differentiation becomes much greater, compared to the absolute values of the salary and pension incomes. .

Table 1. The laws of unitary pay of state employees. Comparative analysis of 2009-2010-2017

\begin{tabular}{|c|c|c|c|}
\hline Field & $\begin{array}{l}\text { Multiplication } \\
\text { coeficient } \\
\text { min } / \max \\
\text { according to } \\
\text { Law } 330 / 2009\end{array}$ & $\begin{array}{l}\text { Multiplication } \\
\text { coeficient } \\
\text { min } / \max \\
\text { according to } \\
\text { Law } 285 / 2010\end{array}$ & $\begin{array}{c}\text { Multiplication } \\
\text { coeficient min/max } \\
\text { according to } \\
\text { Law 153/2017 }\end{array}$ \\
\hline $\begin{array}{l}\text { Army, police, secret } \\
\text { services (including } \\
\text { grade pav) }\end{array}$ & $1,88 / 11.45$ & $1,97 / 11.77$ & $\begin{array}{l}\text { 1,2/4.7 (includig grade } \\
\text { pay) }\end{array}$ \\
\hline Teachers & $2,1 / 4.25$ & $2,1 / 5.36$ & $1,64 / 2.1$ \\
\hline $\begin{array}{l}\text { University } \\
\text { profeessors }\end{array}$ & $2,0 / 7.6$ & $2,37 / 8.16$ & $1,65 / 4.35$ \\
\hline Doctors & $\begin{array}{l}\text { 1,9//5,5/6.2 (UPU, } \\
\text { SMURD)/ } \\
11,25 \text { only for } \\
\text { primary doctor) }\end{array}$ & $\begin{array}{l}2,1 / / / 5,5 / 6.2 \\
\text { (UPU, SMURD)/ } \\
11,25 \text { only for } \\
\text { primary doctor) }\end{array}$ & $\begin{array}{l}2,28 / / 5 / 5,34 \\
\text { (UPU, SMURD)/ } \\
\text { 6,5-only for primary } \\
\text { doctor }\end{array}$ \\
\hline Magistrates & $\begin{array}{l}3,15 \text { (ISM } \\
\text { auditor) } / 7,03 \\
\text { (debutant } \\
\text { judge) } / / 11.7\end{array}$ & $\begin{array}{l}5,63 \text { (ISM auditor)/ } \\
\text { 7,03 (debutant } \\
\text { judge)//12,75/ } \\
\text { 14,93- ÎCCJ, CSM }\end{array}$ & $\begin{array}{l}2,9 / 4,1 / 6 \\
\text { (ISM auditor/second } \\
\text { year/ intern)// } \\
10 / 15 / 16.5 \text { (including } \\
\text { benefits) }\end{array}$ \\
\hline Researcher & $\begin{array}{l}\text { CS 3,11/CS III } \\
3.61 / \text { CSII 4.19/CSI } \\
5.77\end{array}$ & $\begin{array}{l}\text { CS 3,11/CS III } \\
3.61 / \text { CSII 4.19/CSI } \\
5.77\end{array}$ & $\begin{array}{l}\text { CS 1.65/CSIII } \\
1.69 / \text { CSII 2.39/CSI } \\
3.02\end{array}$ \\
\hline
\end{tabular}

Source: Laws establishing unitary salary : Law 330/2009, Law 285/2010, Law 153/2017 
According to this unitary salary law, a newcomer judge receives a salary $50 \%$ higher than the maximum that a university professor can receive and double the maximum of a 1 st grade scientific researcher. All these differences multiply on a much wider scale in terms of the level differences of pensions that magistrates will receive $-80 \%$ of a much higher income, compared to a maximum of $45 \%$, of a much smaller income, in the case of based pensions on contributivity.

As for the other state employees mentioned in comparison, there will also be significant differences between their pensions and those of the magistrates, but, considering that they will also benefit from special pensions, the differences will be proportional (only) to the difference in salary.

As can be seen from the table below, the law of 2017 significantly increases these inequalities, already existing in the previous variants of the law and, by increasing the reference value, the differentiation becomes much greater, compared to the absolute values of the salary and pension incomes.

The lack of real public debate on issues, such as those mentioned above, facilitates the perpetuation and deepening of such inequities generated and sustained by such laws, which become sources of social inequity. This situation is not unique to the public wage system and to the one of special pensions, but is sometimes found in more accentuated forms in norms that regulate the functioning of other institutions as public, but which manage public resources, or obtained from the position of public institution (through taxes, commissions, etc.), in private regime, regarding payroll.

As much as the information on these excessive incomes, sanctioned as such, is conveyed in the media, the absence of debate on real solutions to combat such inequities is absent. The debates do not go beyond the framework set up by a legalistic explanatory paradigm, narrowly legal, of the intangibility of earned rights, a context in which the reconsideration of the more general relationship, between rights and justice, and the relation between law and morality, cannot be called into question.

The second post-communist law of pensions, the one of 2010, proposed the establishment of a unitary system of public pensions. The law provides for an approximation of the retirement age for women and men, the increase of the standard retirement age for women from 60 to 63 years, a minimum internship of 15 years and a complete one of 35 years for both women and men.Another "innovation" introduced with the pension law of 2000 and subsequently amended, is the limitation of the contribution to 3 average salaries in the economy (2001-2003), then to 5 salaries (20032008). Between 2008-2010, this limitation was waived, from 2010-2017 the contribution limitation was reintroduced to 5 gross average salaries in the economy, so that from 2017 this limitation will be renounced.

I brought to discussion these two aspects of the pension law, the ratio to the average wage per economy, respectively, the limitation of the contribution, from the perspective of the distortions they introduced in the social insurance system, with effects on the increase of polarization and social inequity. 
In such a context, the mechanism of indexing pensions with an equal percentage for all pensions represents one of the factors that generate the increase of inequalities within the category of pensioners, by permanently increasing the gap, in absolute value of the level of pensions. Reporting the score based on which pensions are calculated at the average salary per economy transfers the trends of wage polarization to a future polarization of pensions, by artificially increasing this gap, without a direct connection with the level of the contribution. The table below presents the evolution of the pension averages and the pension point, compared with the evolution of the net average salary, taking as intervals of sustained economic growth (2001-2005, respectively 2005-2008), the period immediately following the economic crisis (2012), respectively, the period of sustained growth of pensions, started in 2017.

Table 2. The evolution of average pension/average net salary/pension point value

\begin{tabular}{|c|c|c|c|c|}
\hline Year & $\begin{array}{c}\text { Average } \\
\text { pension }\end{array}$ & $\begin{array}{c}\text { Average net } \\
\text { salary }\end{array}$ & $\begin{array}{c}\text { Pension point } \\
\text { value }\end{array}$ & $\begin{array}{c}\text { Average pension/ } \\
\text { average salary\% }\end{array}$ \\
\hline 2001 & 150 & 366 & 188 & 0.409836 \\
\hline 2005 & 312 & 848 & 296 & 0.367925 \\
\hline 2009 & 832 & 1477 & 732 & 0.563304 \\
\hline 2012 & 900 & 1697 & 733 & 0.530348 \\
\hline 2018 & 1340 & 2957 & 1100 & 0.453162 \\
\hline
\end{tabular}

Source: MMJS, CNPAS

It is interesting to note that the first period of economic growth illustrated with data in the above table has led to a deterioration of the average pension / net average salary ratio, while in the following period of economic growth this ratio has improved significantly, the maximum is found recorded in 2009, in the year in which the effects of the economic crisis began to be felt sharply in Romania.

On the other hand, the gap between the average level of special pensions and that of pensions based exclusively on taxpayers increases significantly in the period 2010-2018 for a single category, that of magistrates. The average pension in this category doubles, starting from a level more than 10 times higher than the average pension, while the average pension for retirement increases, between 2010-2018, by 63.8\%, but the increase in the gap in absolute value is over 8000 lei. The contributing part of the average magistrates' pension increases by 1018 lei, while the non-contributory part increases, from 7609 lei, to 16,302 lei. The question arises as to how this "additional premium" average of almost 9000 lei per month (amount which means almost 7 average pensions based on contributivity) can be justified for magistrate pensioners, starting from a pension level, already at a level above four times the contributory part of their pension. Currently, the ratio between the non-contributing and the contributing part for magistrates is $1: 6.57$. 
Table 3. Evolution of pensions based on contributivity and special pensions (2010-2018)

\begin{tabular}{|c|c|c|c|c|c|c|}
\hline \multirow{2}{*}{$\begin{array}{c}\text { Category } \\
\text { of pensioner }\end{array}$} & \multicolumn{2}{|c|}{$\begin{array}{c}\text { Average level } \\
\text { of pension }\end{array}$} & \multicolumn{2}{|c|}{$\begin{array}{c}\text { Average level of } \\
\text { pension in the ASS }\end{array}$} & \multicolumn{2}{|c|}{$\begin{array}{l}\text { State budget } \\
\text { contribution }\end{array}$} \\
\hline & 2010 & 2018 & 2010 & 2018 & 2010 & 2018 \\
\hline $\begin{array}{l}\text { Retirement } \\
\text { age pensioners }\end{array}$ & 856 & 1340 & 856 & 1349 & 0 & 0 \\
\hline Magistrates & 8691 & 18150 & 1725 & 2760 & 7609 & 16302 \\
\hline $\begin{array}{l}\text { Diplomats and } \\
\text { consuls }\end{array}$ & 4270 & 5480 & 1975 & 2457 & 3249 & 3321 \\
\hline $\begin{array}{l}\text { Aviators/civil } \\
\text { aviation }\end{array}$ & 9162 & 10698 & 1805 & 3265 & 7558 & 7531 \\
\hline
\end{tabular}

Source: CNPAS, 2010. 2018

As I mentioned earlier, the future pensions of the current employees depend on the position of the salary in relation to the average salary and the value of the pension point. Therefore, an employee with an average salary of the active period at the level of the average salary in the economy will have, simplifying the calculation, a pension whose level will represent a percentage of the average salary, of a level close to the percentage recorded by the pension point in the report with the average net salary. If, at the present time, the average pension exceeds by one fifth the value of a pension point, considering the distribution of wages, it is assumed that this percentage will decrease.

Quite the opposite is the case regarding some of the "special" pensioners. While the ratio between the value of the average retirement age pension based on the contribution rate and the value of the pension point was in 2018 of $1: 1.21$, in the case of the retired pensioners this ratio was 1: 16.5.

The pension point represents $41 \%$ of the net average salary (2018) and $23.9 \%$ of the average gross salary. For pensioners with special pensions, the pension represents $114 \%$ of the net average wage, respectively, $73 \%$ of the gross salary.

\section{Conclusions}

In the last three years, in particular, there has been much talk in the public space about justice, about abuses, about fairness. There has been a lot of talk about pension and salary increases.It is true that, as a percentage, both wages and pensions have increased significantly in recent years. In absolute value, however, due to the very low reporting base to which these growth rates were reported, for the vast majority of employees and pensioners, the increases were modest.As a result, most pensions and salaries, despite these significant increases, are still at very low levels, which ensure a standard of living at the limit of survival.

However, pensions remain, despite their low level, the social transfer with the most significant impact on poverty reduction. In the context in which the share of social public expenditure in GDP is constantly below the average of the EU countries, throughout the post-communist period, social transfers, other than pensions, 
contribute to Romania, to reduce poverty to a lesser extent than in any other country in the country. EU. The economic growth is not reflected, except to a very modest extent, in the increase of the share (and not even on the amounts) allocated to public social spending.

Certain types of incomes grow in an accelerated way throughout this period. Among these types of revenues, there is a large part of the salaries and incomes of the members of boards of directors of some state-owned companies and, in particular, of government agencies and regulatory authorities. Some of the so-called special pensions that, due to the laws that regulate them, are growing, accelerated, to levels that can already be considered too high, even for some of the most developed countries of the EU.

The economic crisis was felt strongly in Romania since 2009 and it represented a first moment of the first attempt to place order in the budgetary system and in the public pension system, after a period of 20 years of permanent, reactive legislative changes. and discontinuous that have generated significant inequities in the two systems of income distribution.

In conditions of crisis and shortage of resources, the moral criterion, as a determinant of social equity, becomes an important and very present one in the public space. An important topic addressed in this context was that of discrepancies in the field of state employees salaries and of the so-called special pensions versus the pensions based exclusively on contributivity. There were identified certain categories that could be privileged, categories such as those of aviators and magistrates being considered exemplary in this regard. Also, other categories of privileged employees were identified, from institutions, such as Regulatory Authorities and certain State-owned companies. exchange reduced significantly, the salaries of people already on the verge of survival. Pensions 20 times higher could not be reduced, those being considered "earned rights".

The post-crisis period, especially the last 3 years, has led, in conditions of significant economic growth, to an unprecedented "relaxation" of the moral criterion mentioned above and to the deepening of all these discrepancies and inequities. The concept of rights replaces the public, the one of justice, and the idea of social justice is limited to the rights of those who are presumed to have broken the law.

Income collected by persons appointed to the Regulatory Authorities and to the Boards of Directors increased, unrelated to their performance or to the respective institutions, the higher pensions became even higher, while most salaries and pensions remained at modest levels, even in the conditions in which the percentage increase was an important one, due to the small values to which it was applied, it was not felt to a significant extent in the real growth of these incomes.

In addition, all pensioners, including those with special pensions, were exempted from the CASS payment, for the entire pension, regardless of its amount, as well as the payment of income tax for the first 2000 lei from the pension.

On the other hand, the discrepancies between the contributions-based pensions and the "special" pensions have increased significantly, artificially, as a result of changing the 
way of calculating the taxation of work. The increase of the gross income, felt by the majority of the employees (including and, mainly, those from the private sector) to a rather small extent in the increase of the net salary, was felt, on the other hand, in a very significant measure in the increase of the special pensions, correlated with the gross salary, according to the significant difference in taxation of the two types of income (salaries, taxed, on average, by $42 \%$, pensions, taxed with a maximum of $10 \%$ - only those exceeding 2000 lei and only for the amount that exceeds this threshold).

In the public space, a model of social (in)justice is promoted, in which justice is confused with rights, and the most "unfair" rights are defended, as is evident from the privileges of the legal system, which becomes a defender of their own. rights and a guarantor of injustice.

The institution that should defend the independence of the judiciary reacts harshly to any attempt to temper excesses that already exceed any allowable limits. The "special" part of the special pensions exceeds, in the case of the magistrates, almost seven times or the appropriate part on the basis of the contributivity, with the legal possibility that this non-contributory part will grow, unlimited, (only) for this category of "special", without any connection with the contribution to social insurance, with the salary received during their active period (but with the salary of the currently active ones), with the economic power of the country, by an exacerbation beyond any limit of the merits of some merits, in relation to others. This, given the fact that Romania continues to be the country with the second highest poverty rate in the EU, with the highest poverty rate of children and families with more than three children, with a much higher poverty rate. above the European average, with the highest rate of functional illiteracy situations in which there is no public pressure "to do justice" and which do not, in any way, concern those who are the "guarantors" of justice.

Instead of conclusions, I think a question would be appropriate for those who (while "doing justice") promoted and voted laws that made it possible for certain benefits granted to privileged members of the system to reach levels like the ones mentioned above. or, as in the case of the child-raising allowance (when the maximum ceiling was removed by law) benefits (non-contributory, but which involved only a minimum contributory condition), which represented the correspondent of more than 100 average pensions due for social contributions paid for 35 years. The contribution condition for the allowance of 35,000 euros per month was 2 years. The ceiling was reintroduced, in the meantime, but the money was paid. According to MMJS the amount paid can be recovered in more than 200 years, if the respective one will pay taxes and taxes at the same level in all 200 years.

The question arises which was the moral, social or economic criterion for which, by the laws proposed to do justice, a salary of 2000 lei would be taxed by over $40 \%$, while a pension, in some cases, and 20-30 times higher (not entirely contributive), to be taxed by approximately $9 \%$ ? This, while those who already received pensions more than ten times higher than the average pension, received a "gift" equivalent of several average monthly pensions, only by changing the tax system. guarantees that things should continue to be the same, at least in the case of retired magistrates, for whom pensions that have already reached are more than ten times higher than, for example, doctors, 
"only partially compensate for incompatibilities and restrictions of rights in the active period "(all these vicissitudes probably being considered" incomparable "with those suffered, for example, by war veterans, or former political prisoners, for whom the compensation is tens of times smaller, that is, in the case of those who continue to receive them).

The examples, although some are chosen to be illustrative, are not some isolated and do not cover, by far, the whole spectrum of social inequalities certified by laws that clearly and unequivocally benefit certain categories of privileged. More seriously, in the context of the moral confusion analyzed in this chapter, it seems to me that in the public space people have appeared who, encouraged by certain sites and even television stations, have justified such excesses, even appealing to principles such as those of fairness and justice. In the case of capping the child-raising allowance to a level that exceeds the maximum level granted in Germany, there were Associations of parents who protested against the cancellation of the right to receive, possibly, 35,000 euros per month for two years, ie to receive $80 \%$ of income, after having contributed $0.85 \%$ of income for two years.

What I wanted to discuss in this analysis is the lack of moral foundations of the laws. Social injustice affects social cohesion and trust in laws perceived as immoral. According to an IMAS survey, from May 2019, over three quarters of Romanians declare themselves totally against special pensions, and these, not only do they not decrease, but they continue to increase, an even faster way, through the effect of laws and regulations.

A society based on meritocracy cannot function by exacerbating beyond limits, some merits, to the detriment of others and by discretionary allocation of resources, to "compensate" (through pensions)) situations already overcompensated by the high level of wages (as well as by other benefits that we have not discussed here) while no resources are found to increase the Social Reference Index, to which social assistance benefits for the most disadvantaged people are reported.

Social inequity and injustice cannot be justified, by the end, through the pseudo-moral of the rights won, and the connection between law and morals must be restored. Social justice is not a fuss, and social justice is an essential condition of the functionality of social systems.

\section{References}

Barry, B. (1989). A Treatise of Social Justice. vol 1. Theories of Justice, London: HarvesterWheatsheaf

Barry, B. (1995). Justice as Impartiality. Oxford: Clarendon Press

Boudon, R. et al. (1997) Larousse.Dictionar de sociologie, Bucharest: Univers Enciclopedic

Bădescu, I. (1996) Istoria sociologiei- teorii contemporane, Bucharest: Editura Eminescu

Larionescu, M., Mărginean I., Neagu, G. (2006). Constituirea clasei mijlocii în România, Bucharest: Editura Economică

Manolache, V. (2009) Elite în mars, Sibiu: Editura TehnoMedia

Miroiu, A. (1996). Teorii ale dreptătii, Editura Alternative 
Mărginean, I. (2007). Politici de reformă în domeniul pensiilor, Revista Calitatea Vieţiii, (3-4)

Mărginean, I. (2011.) Legea 263/2010 privind sistemul unitar de pensii publice, Revista Calitatea Vieții, (2)

Profiroiu, M. C., Iorga, E. (2009). Manual de politici publice, IPP

Preotesi, M. (2015). O analiză a mesajului media, a promotorilor lui și a intereselor lor la televiz̨iunile de știri din România, in Dumbrăveanu A. (coord.) (2015). Informarea versus manipularea electoratului,Chişinău : USM, p.90-105

Preotesi, M. (2010). Solidaritatea socială în criză, Revista Inovația sociala, (2). Available on www.inovatia socială.ro

Preotesi, M. (2014). Polarizing mechanisms and factors of the middle class in transition, Procedia Economics and Finance, 8 p. $576-581$

Preotesi, M. (2016). Groups and Needs: Response of the Social Protection System in Nowadays Romania, Revista de Cercetare si Interventie Sociala, (55), p. 139-157

Preotesi, M. (2018). Eficiența sistemului de protecție socială în reducerea sărăciei. Comparație România-țări din UE, Revista Sociologie Românească, (1-2)

Rawls, J. (1971). A Theory of Justice. Cambridge: Harvard University Press

Vasile, M. (2007). Stratificare socială în România, Revista Calitatea Vieţii, (3-4), p.339-381

Zamfir, C. (coord.) (1999). Politici sociale în România, 1990-1998, Bucureşti: Editura Expert

Zamfir, E. (coord.) (2000). Strategii antisărăcie și dezvoltare comunitară, București: Editura Expert

Zamfir C., Ilie S., Stănescu I. (coord.) (2010). Raportul social al ICCV După 20 de ani: Opțiuni pentru România, Academia Romană,

Zamfir, C., (coord)., Ilie S., Stănescu I., Scutaru C., Zamfir E. (2011) Raport social al ICCV Romania: răspunsuri la crižă, Academia Romană

Direcția Informatică şi Evidență Stagii de Cotizare. www.cnpas.org. Accesed on june 2019

https://stirileprotv.ro/stiri/politic/ministrul-muncii-indemnizatiile-pentru-cresterea-copiluluivor-fi-plafonate-la-un-maximum-1-800-de-euro-pe-luna.html_.Accessed on june 2019

https://www.luju.ro/dezvaluiri/evenimente._Accesed on june 2019

https://www.rfi.ro/presa-romaneasca-113047-de-ce-tipa-csm-adevarul_Accessed on june 2019

https://evz.ro/magistratii-pensionari-se-ridica-impotriva-suprataxarii-veniturilor-lor.html.

Accessed on june 2019 